\title{
AULA DE LEITURA NA PERSPECTIVA DIALÓGICA: UMA ELABORAÇÃO DIDÁTICA COM MEMES
}

\author{
READING AND LINGUISTIC ANALYSIS LESSONS IN THE DIALOGICAL \\ PERSPECTIVE: \\ A DIDACTIC ELABORATION USING MEMES
}

\section{Lilian Cristina Buzato Ritter ${ }^{1}$ Betânia Elisabete Braga da Silva²}

\begin{abstract}
Resumo: $O$ artigo trata de uma reflexão da forma de mobilização das noções teóricometodológicas bakhtinianas de dialogismo e gênero discursivo, em atividades elaboradas para aulas de leitura e análise linguística com memes. As relações dialógicas são contempladas nas questões sobre condições de produção, enfatizando seu espaço-tempo de circulação, endereçamento a seus interlocutores, finalidade. A noção gênero discursivo suscita análise do conteúdo temático por meio do que se torna dizível; o tom de ancoragem valorativa; em relação à estrutura composicional, o destaque é para o visual e verbal; e, ao estilo, as marcas linguísticoenunciativas da relação entre a forma visual e verbal.
\end{abstract}

Palavras-chave: leitura; análise linguística; meme.

Abstract: The article deals with a reflection on the form of mobilization of the Bakhtinian theoretical and methodological notions of dialogism and discursive genre, in activities designed for reading and linguistic analysis classes using memes. The dialogical relations are contemplated in questions about conditions of production, emphasizing their space-time of circulation, addressing their interlocutors and purpose. The notion of discursive genre raises analysis of the thematic content by means of what becomes veritable; the value-anchoring tone; regarding compositional structure, the highlight is for the visual and verbal; and, in style, the linguistic-enunciative marks of the relation between visual and verbal form.

Keywords: reading; analysis; linguistic; meme.

\section{Introdução}

Apesar de, por mais de duas décadas, pesquisadores da área da Linguística Aplicada dedicarem-se a trabalhos voltados ao ensino da leitura, alicerçando alguns avanços teóricometodológicos, no que diz respeito à referida prática na concepção interacionista de linguagem,

\footnotetext{
${ }^{1}$ Doutora em Estudos da Linguagem pela Universidade Estadual de Londrina (UEL). Docente do Mestrado Profissional em Letras em Rede Nacional (ProfLetras) da Universidade Estadual de Maringá (UEM). Desenvolve pesquisas vinculadas ao Círculo de Bakhtin. E-mail: bliliancristina@ hotmail.com

${ }^{2}$ Mestranda em Letras pela Universidade Estadual de Maringá (UEM). E-mail: betaniaelisabete@ hotmail.com
} 
atualmente, um dos grandes desafios da escola ainda se encontra relacionado ao desenvolvimento de leitores críticos.

Tanto documentos oficiais nacionais - no caso, os Parâmetros Curriculares Nacionais (BRASIL, 1998) e, mais recentemente, a Base Nacional Curricular (BRASIL, 2017) - e regionais sobre política educacional - no caso do Paraná, as Diretrizes Curriculares da Rede Pública de Educação Básica do Paraná (PARANÁ, 2008) - elegem como objetivo das aulas de leitura o desenvolvimento de atitudes e posturas críticas do leitor frente aos textos. Nessa direção, podemos afirmar que esses documentos são permeados por diversos aportes teóricos, como por exemplo, os da Linguística Textual, da Psicologia Cognitiva, da Análise do Discurso, dos Estudos da Enunciação, e entre todas essas contribuições há uma convocação para a noção bakhtiniana de gênero discursivo.

Uma das implicações pedagógicas essenciais dos pressupostos da teoria bakhtiniana à prática de leitura, na concepção de linguagem como interação social entre os sujeitos, é o aspecto dialógico como dimensão constitutiva da linguagem (BAKHTIN; VOLOCHINOV, 1988; BAKHTIN, 2003). No que tange à compreensão das bases teóricas do Círculo, é muito importante a premissa das relações dialógicas como relações de sentido entre os enunciados, sendo o sentido inscrito em vozes discursivas. Dessa maneira, na teoria dialógica do discurso, a produção de sentidos pressupõe:

(...) por um lado, descartar qualquer possibilidade de limitação e redução de sentidos, e, por outro, preservar as ressonâncias de outros ditos, já-ditos e/ou não-ditos na linguagem. Os sentidos, a partir da abordagem dialógica, projetam-se como efeitos, sendo assim, irredutíveis a uma só possibilidade apesar de em determinados contextos enunciativos haver sentidos predominantes. Com isso, os efeitos de sentidos existem a partir de construções discursivas, das quais o sujeito "não é a fonte de seu dizer", uma vez que se constitui, de modo dinâmico, com a instituição histórico-social (DI FANTI, 2003, p. 98).

Retomando em Bakhtin (2003) a ideia de que toda compreensão é de natureza ativamente responsiva e prenhe de resposta, ela não equivale ao reconhecimento da forma linguística, mas, sim, à instauração de possíveis diálogos com o texto e, como tal, exige o reconhecimento do outro, “(...) porque lendo a palavra do outro, posso descobrir nela outras formas de pensar que, contrapostas às minhas, poderão me levar à construção de novas formas, e assim sucessivamente" (GERALDI, 1991, p. 171). O resultado do movimento dialógico do leitor em reconhecer o outro na leitura de um texto-enunciado é a contrapalavra, que, nesses termos, funciona como característica da compreensão responsiva ativa. A compreensão de um 
enunciado sempre provoca no leitor uma atitude de reação-resposta que pode se manifestar pelo ato de discordar, concordar, parafrasear, ampliar, admirar, contemplar, silenciar... Enfim, os movimentos de reação-resposta instaurados no processo de produção de sentidos do discurso constituem o caráter responsivo de todo enunciado. Assim, no eixo leitura, corroboramos Rojo (2005, p. 207), quando afirma que “(...) trata-se mais de despertar a réplica ativa e a flexibilidade dos sentidos na polissemia dos signos, que de ensinar o aluno a reconhecer, localizar e repetir os significados dos textos (...)".

Na mesma direção, pautados nas palavras de Acosta-Pereira e Rodrigues (2016, p.40), podemos considerar que a prática de leitura incide sobre os projetos de dizer do outro, "além de possibilitar a compreensão valorativa da palavra alheia, reconhecendo outras vozes entretecidas e as diversas relações dialógicas constituídas semântico-axiologicamente”. Sendo, portanto, o texto-enunciado uma resposta aos já-ditos, a leitura é uma prática social em que sujeitos, com diferentes projetos de dizer buscam compreender o dizer de outrem e reagir responsivamente a esse dizer.

É nesse sentido, que se afirma: no momento da leitura, "parece-nos ser mais útil e necessário explorar com eles (alunos) as características das situações de enunciação relacionadas às marcas linguísticas que deixam" (ROJO, 2005, p. 207). Ou seja, estamos pensando em uma prática de leitura mediada pela prática de análise linguística, na qual o textoenunciado pode ser considerado como a materialização das escolhas linguístico-enunciativas feitas pelo sujeito-autor; processo em que a reflexão sobre a língua deve estar situada a partir da situação concreta em que foi produzida (atividades epilinguísticas), para só depois, voltarse ao linguístico e sua composição (atividades metalinguísticas) (ACOSTA-PEREIRA; RODRIGUES, 2016).

Após esclarecermos ao leitor as concepções de linguagem, de leitura e análise linguística em que nos ancoramos, neste momento, pontuamos o objetivo deste trabalho: discutir, à luz de um processo de elaboração didática de aulas de leitura e análise linguística, a forma de mobilização das noções teórico-metodológicas bakhtinianas de dialogismo e de gênero discursivo. É importante salientarmos que a referida elaboração didática está inserida no trabalho final do Mestrado Profissional de Braga (2018) e ancora-se teoricamente na perspectiva dialógica da linguagem (BAKHTIN; VOLOCHINOV, 1988; BAKHTIN, 2003). Dessa forma, a fim de promover a discussão dos aspectos teórico-metodológicos mobilizados para a elaboração da referida proposta, neste artigo, selecionamos uma das partes que 
constituíram todo o processo de elaboração didática, a produção do material didático de leitura e análise linguística de memes em um módulo, no caso, o que tratou do tema homofobia, para um nono ano da rede pública paranaense de ensino.

A fim de organizar este artigo, primeiramente, apresentamos, brevemente, os fundamentos teórico-metodológicos que nortearam este estudo, com destaque para conceitos formulados pelo Círculo de Bakhtin, para o gênero meme e para o conceito de elaboração didática da pedagogia francesa. Em seção posterior, caracterizamos a mobilização das noções teórico-metodológicas constituintes da proposta didática de leitura e análise linguística elaborada.

\section{Sobre dialogismo e o gênero discursivo meme}

Ao defender o dialogismo como um aspecto constitutivo da produção de todo discurso, a teoria bakhtiniana critica os estudos realizados, à sua época, nas áreas da filosofia da linguagem e da linguística, por terem deixado de fora do escopo de suas análises justamente a questão da dialogicidade interna do discurso, que nessa perspectiva, pode ser considerada a força criativa da linguagem. Do ensaio $O$ discurso no romance, publicado em Questões de literatura e estética: a teoria do romance, reproduzimos um exemplo, entre as inúmeras recorrências, da convicção bakhtiniana:

(...) É justamente esta dialogicidade interna do discurso, que não aceita formas dialógicas externas de composição, que não se destaca como ato independente da concepção que o discurso tem de seu objeto que possui uma enorme força de estilo. Encontra ela sua expressão na série de particularidades da semântica, da sintaxe e da composição, que não foram ainda estudadas pela linguística e pela estilística (...) (BAKHTIN,1998, p. 88).

Na discussão feita por Sobral (2009), pelo viés da teoria bakhtiniana, o autor esclarece porque o dialogismo é um conceito amplo, que abrange os planos de cunho filosófico, discursivo e textual. Em primeiro lugar, argumenta que o caráter dialógico é condição essencial do próprio ser e agir dos sujeitos. Isso porque a existência do sujeito está condicionada à relação com outros sujeitos, assim como suas ações só encontram sentido em função das ações do outro. Discursivamente, como já consideramos, as relações dialógicas constituem-se como condição de possibilidade da produção de sentidos. O sentido nasce de diálogos entre enunciados já-ditos e os que estão a vir, por parte do interlocutor. Já no âmbito textual, o dialogismo é a base do diálogo enquanto uma forma de composição de enunciado. No entanto, Sobral (2009) assinala 
que o dialogismo não se restringe às formas mostradas ou não mostradas da representação do diálogo no discurso.

Apesar de haver formas monológicas e dialógicas, quanto a esse aspecto mais restrito do dialogismo, Sobral (2009) destaca o posicionamento bakhtiniano de que nenhum enunciado pode ser constitutivamente monológico, no sentido filosófico e discursivo. Considerando-se que o discurso é constituído pelo confronto de vozes discursivas heterogêneas, sendo que toda palavra é carregada e preenchida pela apreciação valorativa de seu locutor, não podemos conceber um discurso monológico que neutralize todas as vozes do outro. O que pode existir são discursos com "tendências monológicas", nos quais são utilizadas estratégias discursivas para se tentar ocultar as vozes do outro na materialidade textual.

À luz do dialogismo, a linguagem pode ser considerada uma reação-resposta a um jádito em uma determinada situação de interação verbal, que manifesta a tensão entre as relações do locutor com os enunciados do outro. O outro não é entendido somente como o interlocutor físico, mas, principalmente, como as posições sociais assumidas por ele a partir de discursos diversos que permeiam a sociedade. Essas outras vozes discursivas constituem o discurso de forma heterogênea e apresentam-se em diferentes níveis no enunciado, instaurando o princípio da alteridade. Nessa perspectiva, reiteramos a definição de que o dialogismo é constitutivo em termos arquitetônicos de toda a produção de discursos; logo, a relação com os sentidos produzidos é sempre dialógica.

Tratando-se, de modo específico do meme, corroboramos a ideia de Silva (2016) sobre ele ser um gênero essencialmente dialógico, porque:

Conserva em si ressonâncias de outros discursos, de outros gêneros oriundos de outras esferas da atividade humana, que o constituem como gênero. Todo meme rememora outros memes (e também outros gêneros), porque com eles dialoga: seja por meio do estilo, da estrutura composicional, do conteúdo temático. (...) (SILVA, 2016, p. 352)

É preciso retomar o conceito de multiletramento e de hipermodernidade para explicar como a teoria de gêneros discursivos coaduna com a evolução alcançada pelas tecnologias de comunicação. Neste sentido, destacamos as ideias de Rojo e Barbosa (2015):

(...) Para quem se ressentia da ausência de comprovações empíricas mais evidentes e diretas para aceitar as postulações de Bakhtin, eis que os funcionamentos hipermidiáticos e em rede e a prática da remixagem envolvendo diferentes modalidades de linguagem as trazem e encarnam de forma cabal. (ROJO; BARBOSA, 2015, p. 120-121) 
As autoras explicam que, nas últimas décadas, surgiram novas formas de ser, de se comportar, de discursar, de se relacionar, de se informar, de aprender. Não são as tecnologias que modificam as pessoas, mas as pessoas se modificam e buscam novas tecnologias que reflitam essas mudanças. A internet trouxe a possibilidade de qualquer um ser produtor ou leitor de conteúdo, como afirmam Rojo e Barbosa (2015), possibilitando que todos publiquem na rede e exerçam simultaneamente os dois papéis. As redes sociais abriram as portas para a autoexposição, tendo em vista que nos tempos do hiper (hiper modernidade, hiper conectividade, hiper hedonismo) não basta viver, é preciso contar o que se vive.

Diante desses fatos, o meme surgiu para dar voz a quem deseja expressar suas opiniões, por isso a quantidade de releituras de uma mesma imagem, fato, vídeo, comentário em rede social. Basicamente qualquer expressão, em rede social, é passível de se transformar em meme. Esse pensamento expande o que imaginamos por discurso, pois na internet ele pode se organizar de muitas maneiras inesperadas, e a originalidade como se apresenta é uma das premissas para que um meme seja viral. Ainda, na visão de Silva (2016), a função inicial de um meme na rede virtual pode ser particular, na medida em que diz respeito à intenção de um usuário específico, mas, se sua replicação se tornar viral, sua função se torna "socialmente conhecida" (SILVA, 2016, p. 349).

Portanto, o meme, na visão de Silva (2016, p. 348), atende “(...) às características prototípicas de um gênero discursivo, inclusive pelo fato de apresentar um projeto de dizer, conteúdo temático, estilo e estrutura. $\mathrm{O}$ autor ressalta ainda, em relação ao projeto de dizer de um meme, a variedade de valores e funções que este gênero pode desempenhar no espaço virtual. Além das intenções humorísticas e satíricas, o meme pode também provocar uma reflexão, problematizar uma situação e, nas palavras do autor: “(...) tudo isso parece ter a ver com o conteúdo temático, com a esfera da atividade a que se relaciona o produtor de um meme." (SILVA, 2016, p.349).

Esta explicação retoma o conceito de conteúdo temático, que pode ser entendido como o conjunto de conteúdos ideologicamente abarcados através do gênero - o que pode ser dizível numa determinada forma genérica - e nascidos da interação dialógica. Como Rojo e Barbosa (2015) destacam, o gênero meme encontra-se na esfera da vida pública, nas redes sociais, nas perspectivas de produção e consumo. Pode ter temas políticos, propagandas, temáticas sociais, na maioria das vezes, pelo viés do humor e da sátira, propondo novas formas de mobilização e manifestação de participação social, principalmente para a juventude. 
Em relação à estrutura composicional, para a teoria bakhtiniana, a forma composicional de um gênero, apesar de apresentar um aspecto mais fixo, se comparada ao tema e ao estilo, também está vinculada à forma arquitetônica, determinada pelo projeto enunciativo do locutor (SOBRAL, 2009). Nesse sentido, Rodrigues (2001) postula que a diversidade e a heterogeneidade composicional de um gênero são proporcionais à criatividade e complexidade da atividade humana. Acrescenta que a composição estrutural não pode ser associada apenas à organização textual, porque cada gênero vincula-se a uma situação social de interação verbal, dada uma esfera social e uma finalidade discursiva. Não podemos deixar de considerar que, dependendo do tipo de relações sociais estabelecidas nas esferas de comunicação discursiva, as formas composicionais dos gêneros podem ser mais ou menos rígidas. Dessa forma, no caso do meme, podemos afirmar que é uma hipermídia de base fotográfica, mas não apenas nela se estrutura, pois também pode apresentar textos verbais, imagens em movimento (gifs) e até vídeos curtos.

Por último, tratamos do estilo. No capítulo intitulado Os gêneros do discurso, Bakhtin (2003) dedica maior atenção à questão do estilo, justamente por ser de seu interesse avançar na questão dos estudos estilísticos feitos até aquela época. No início desse texto, o autor afirma a existência de uma união orgânica e indissolúvel entre o estilo e o gênero: "Em cada campo existem e são empregados gêneros que correspondem às condições específicas de dado campo; é a esses gêneros que correspondem determinados estilos" (BAKHTIN, 2003, p. 266). Porém, essa relação não se dá em uma única direção, pelo fato de mudanças de estilo poderem alterar a forma composicional de um determinado gênero, evoluindo para outro gênero.

Outro ponto relevante em relação ao estilo, é que, conforme Rodrigues (2001), no percurso do dialogismo ao gênero, como outros conceitos do Círculo, ele é uma construção dialógica, social, ideológica. Portanto, o estilo é determinado pelas relações dialógicas estabelecidas entre os interlocutores e, destes, com todos os elementos da situação sócioenunciativa. Na construção do estilo entram em cena como fatores determinantes a atitude valorativa do locutor frente ao aspecto temático, aos interlocutores e aos enunciados já-ditos e aos pré-figurados. Sendo assim, embora o meme seja um gênero relativamente novo, seus pressupostos sócio-enunciativos não são. Ele preconiza a ironia, a sátira, a imitação, a amplificação, que não são novidade. Portanto, o estilo do meme será determinado pela relação muito próxima entre ele e as necessidades do nosso momento histórico, quando as pessoas 
desejam construir uma imagem que as defina, buscando "revelar-se" aos olhos do mundo na tentativa de alimentar seu ethos.

Finalizamos esta seção e passamos à seguinte, contemplando o conceito de elaboração didática.

\section{Sobre elaboração didática}

No entendimento de ser preciso ressignificar o conceito de transposição didática, Halté (2008) propõe o conceito de elaboração didática, jogando mais luz no processo de reelaboração de conhecimentos constituídos pela pluralidade de saberes do que no ato da transposição. O autor defende uma concepção didática praxiológica, visto que as aulas de leitura ou de produção de texto em língua materna convocam saberes de todos os tipos, afirmando: “(...) na prática de sala de aula, o saber científico, a prática social de referência, a especialidade e o conhecimento estão literalmente sincretizados" (HALTÉ, 2008, p. 131). Sem a sincretização dos saberes não haveria condições favoráveis à apropriação, e à luz dessa perspectiva praxiológica, os saberes antes hierarquizados agora encontram-se solidarizados. Ademais, na visão do autor, os conteúdos a ensinar refratam práticas sociais, não se reduzindo a saberes científicos simplesmente transpostos. No intuito de contribuir com o enriquecimento do conceito de transposição didática, o autor propõe duas categorias que levam em conta a tríade didática aluno/professor/o saber - apresentadas como as representações e o contrato didático.

O pesquisador define a categoria representações como produtos das construções das práticas de socialização heterogêneas (família, amigos, mídia, formação escolar,...) que se materializam nas crenças, nos discursos e nas ações dos indivíduos. Tanto para os alunos quanto para os professores, elas fornecem um quadro interpretativo e identitário que orientam os modos de apropriação dos saberes e, no caso do professor, as ações docentes. Espera-se que a categoria contrato didático, por referir-se “(...) aos modos de estabelecimento, no interior do sistema didático e com base na assimetria constitutiva entre professor e alunos, dos lugares de cada ator em face dos saberes ensinados e das atividades" (PETITJEAN, 2008, p. 107), possa auxiliar os professores a compreender melhor os rituais envolvidos nas relações professor/aluno e aluno/aluno e as relações destes com o saber.

$\mathrm{O}$ autor discute, nessa linha de raciocínio, o fato de a escola se caracterizar como o lugar do ensino intencional, em função de ser um lugar construído historicamente para "importar saberes e transmiti-los de forma dirigida", e por esse viés, pode-se considerar os atos didáticos 
artificiais por construção. Nesse sentido, o professor age intencionalmente (de maneira reflexiva) para provocar ou criar situações favoráveis à aprendizagem do aluno. Assim, no geral, o próprio autor caracteriza a noção proposta por uma metodologia implicacionista, pressupondo que no ensino de língua materna os conteúdos científicos transformam-se em conteúdos procedimentais, denominados saber fazer.

Aproximando tais discussões ao ensino de Língua Portuguesa, a partir da apropriação do conhecimento sobre os gêneros discursivos, Viana (2010) esclarece que "não se quer, em primeira instância, um ensino unicamente conceitual, em que o aluno saiba apenas reconhecer ou dizer o que são os gêneros do discurso, mas um ensino procedimental que implique um saber fazer" (VIANA, 2010, p. 5). Dessa forma, defendemos que o saber fazer leitura mediada pela análise linguística, no conceito de elaboração didática, está atrelado à ação do professor planejar situações que propiciem uma efetiva reflexão sobre os aspectos enunciativos envolvidos no funcionamento sócio-discursivo dos gêneros, para que, posteriormente, o aluno possa se questionar a respeito desses elementos em outros momentos que requeiram a adoção de gêneros ainda não apropriados por ele.

A fim de apresentarmos a proposta didática elaborada e suas implicações teóricometodológicas em um processo de elaboração didática, passamos à seção seguinte.

\section{Sobre a proposta didática e suas noções teórico-metodológicas subjacentes}

Voltando ao momento de elaboração didática, a proposta didática foi planejada para uma turma de nono ano, de uma escola da rede estadual do Paraná, situada em uma cidade do interior do estado, que atende, em sua maioria, alunos das regiões periféricas da cidade, pertencentes às classes consideradas socioeconomicamente baixas. Os alunos da turma em questão possuíam um histórico de indisciplina, violência, desmotivação, evasão escolar e reprovações.

Neste contexto educacional foi implementada uma proposta didática de $20 \mathrm{~h} / \mathrm{a}$ com o gênero meme. Em sua configuração geral, ela foi constituída por quatro eixos temáticos que abordam grandes exemplos de "intolerâncias sociais" (GARCIA; SILVA; FELÍCIO, 2012): bullying, racismo, machismo e homofobia. Assim, para compor cada eixo temático foram selecionados memes que remetem aos tipos de intolerâncias sociais escolhidas como temas e outros textos pertencentes a outros gêneros discursivos relacionados aos memes por questões temáticas. 
Este artigo apresenta um recorte da proposta didática, o qual trata do módulo temático da homofobia, elaborado para ser desenvolvido em 05 h/a. Neste sentido, o objetivo geral do módulo é criar condições favoráveis para que o aluno “(...) qualifique suas práticas da web, na perspectiva da responsabilização, (...) (para que possa) refletir sobre participações, avaliar a sustentação das opiniões" (ROJO; BARBOSA, 2015, p.135), revendo assim, suas posturas diante de memes com conteúdos homofóbicos. Na sequência, seguem as atividades da primeira fase do referido módulo.

\section{$1^{a}$ fase: Aula 1}

A primeira aula busca provocar no aluno sua atitude responsiva em relação ao tema "homofobia". Neste momento, o aluno lê alguns memes selecionados com conteúdo homofóbico para expor livremente suas impressões de leitura. Os memes selecionados para esta aula são os apresentados na sequência.

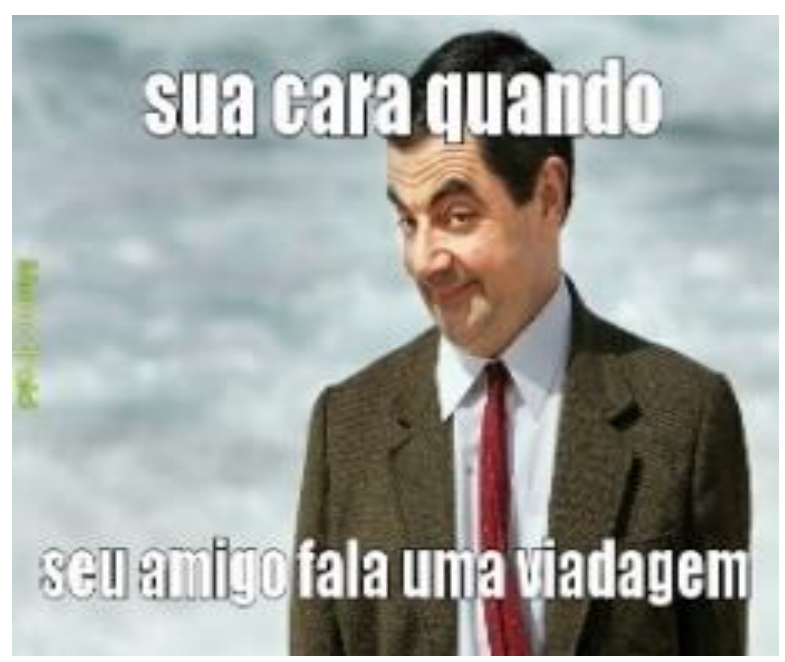

Figura 1- Meme Mr. Bean. Fonte: Whatsapp.

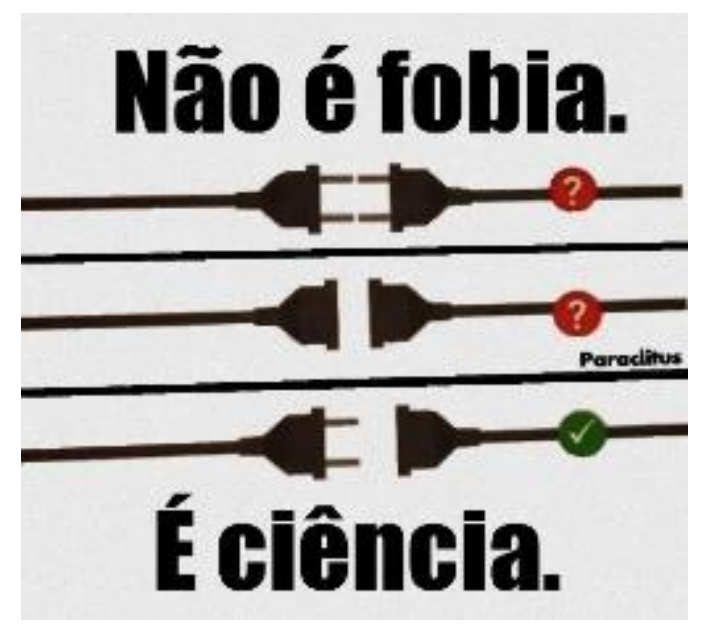

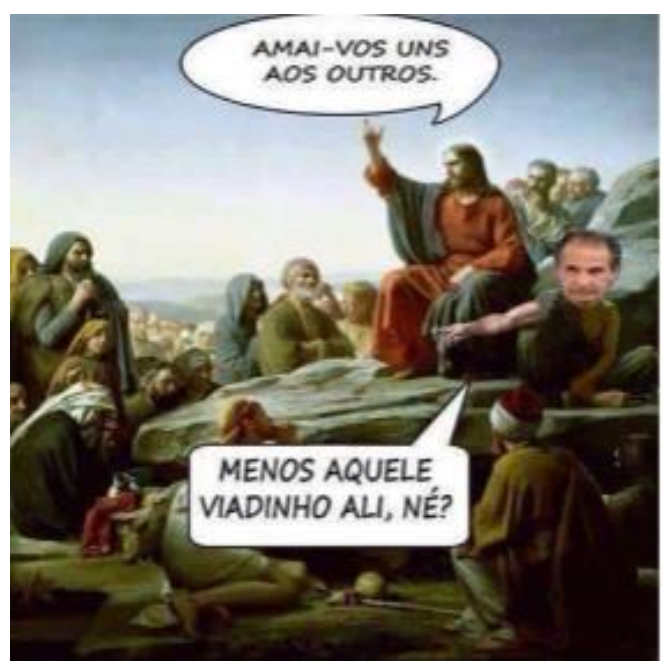

Figura 2 - Meme amai-vos. Fonte: Whatsapp

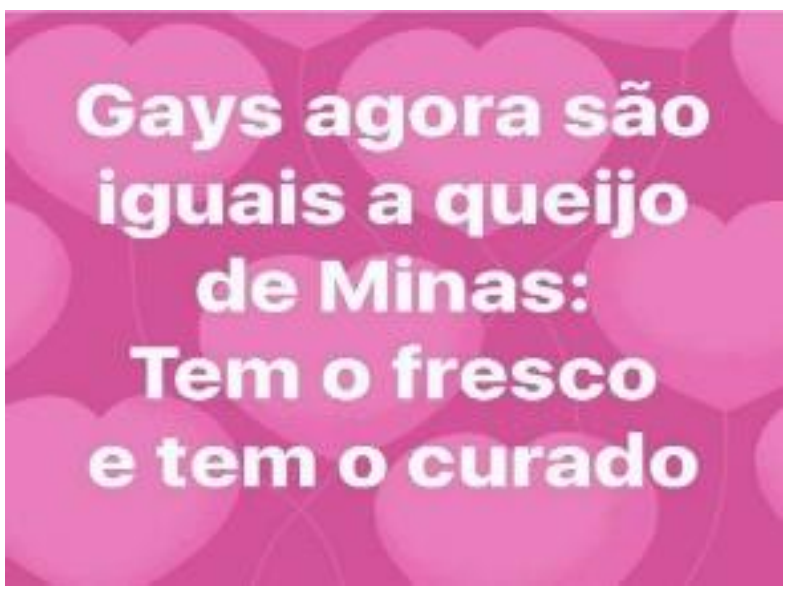


Figura 3 - Meme não é fobia.

Fonte: Whatsapp.
Figura 4 - Meme gay é queijo curado.

Fonte: Whatsapp.

Primeiramente, é importante observarmos que, por estar subsidiada nos pressupostos bakhtinianos de linguagem e nas propostas teórico-metodológicas dos estudos de Rojo (2005), Rodrigues (2008), Hila (2009), Ritter (2012), a aula pode ser iniciada com a reflexão sobre aspectos pertinentes à dimensão sócio-histórica do texto-enunciado, no caso, os memes. Por isso, sugere-se ao professor que instigue uma discussão por meio de questões orais para abordar alguns aspectos relacionados a categoria das condições de produção dos enunciados selecionados, como por exemplo:

a. É possível que algum de seus amigos envie um desses memes para você? Por quê?

b. Se você recebesse um desses memes pelo whatsapp você compartilharia? Para quem? Por quê?

Percebemos que, por meio desses questionamentos, o aluno tem condições para uma reflexão a respeito da finalidade da interação em que este enunciado circula, do conteúdo temático dos memes e da sua posição social enquanto interlocutor nesta situação de interação. Dessa forma, em primeiro lugar, sugerimos a ênfase a essas características da esfera de comunicação em que pertence o gênero e da sua situação de produção.

A seguir, apresentamos os encaminhamentos da $2^{\text {a }}$ fase do trabalho.

\section{$2^{\mathrm{a}}$ Fase: Aulas 2 e 3}

Para estas aulas foi selecionada uma propaganda da loja "O Boticário" sobre o dia dos namorados, veiculada em horário nobre da televisão aberta, no ano de 2015, que causou grande polêmica nas redes sociais por fazer referência a relacionamentos homoafetivos. O vídeo está disponível em https://www.youtube.com/watch?v=p4b8BMnolDI.

Após a leitura da propaganda televisiva, o professor distribui para a sala uma lista de comentários que opinaram a favor ou contra o conteúdo homoafetivo presente na propaganda. No recorte feito, encontram-se opiniões favoráveis e desfavoráveis que focam a questão da homofobia. É importante copiar integralmente a página dos comentários para não 
descaracterizar o gênero comentário. O objetivo de ler os comentários é reconhecer nas opiniões desfavoráveis e/ou favoráveis o discurso homofóbico.

Assim, a primeira atividade é solicitar ao aluno para identificar os comentários em dois grupos: os que gostaram da propaganda e os que não gostaram, destacando os argumentos utilizados em cada um. Ao final, o aluno deve observar que os comentários que deram opiniões contrários usam muitas palavras de baixo calão e, na maioria das vezes, é raivoso e sem um argumento, caracterizando um discurso homofóbico.

Nessas atividades, identificamos a preocupação em propiciar ao aluno a observar a reação-resposta presentes nos comentários que estabelecem um movimento dialógico de distanciamento que desqualifica a propaganda, e, ao mesmo tempo, estabelece um movimento dialógico de assimilação do discurso homofóbico, por meio, principalmente, de palavras ou expressões avaliativas, como os xingamentos, e do chamamento do discurso do outro, como por exemplo, a citação de passagens bíblicas. Portanto, podemos afirmar que nesta atividade de leitura a categoria teórico-metodológica mobilizada é a do dialogismo, pois prioriza a reflexão a respeito da relação dialógica com elos anteriores, referindo-se aos enunciados já-ditos, no caso, a propaganda, e a relação dialógica com elos posteriores, orientando-se aos enunciados pré-figurados, isto é, a futuras enunciações possíveis do interlocutor, no caso, os comentários.

Na sequência das aulas, o aluno efetua a leitura analítica dos memes da $1^{\text {a }}$ fase, a fim de explorar as dimensões constitutivas do gênero e do enunciado (dimensões social e verbal/semiótica). Para tanto, o aluno retoma os memes da fase 1, a partir de questões referentes às condições de produção, conteúdo temático, estrutura composicional e estilo, apresentadas a seguir (assinalamos que as questões propostas foram adaptadas e/ou assimiladas de Maciel e Takaki (2015). Nessas aulas é essencial que o aluno discuta, comente e conheça as condições de produção e de circulação do gênero referente aos textos-enunciados, o meme. Adiante, expomos as atividades sobre as condições de produção dos enunciados.

Questões referentes às condições de produção (retomar todos os memes da fase 1)

- O que esse meme nos diz sobre os tipos de contexto nos quais ele é replicável?

- Onde este meme se encontra a respeito do relacionamento que infere entre as pessoas rapidamente infectadas por ele? O que isso nos diz sobre sua finalidade?

- O que esse meme significa - no espaço em que é replicável, para certas pessoas, e neste tempo em particular? 
Podemos destacar que o movimento de criação dos exercícios contemplou, de modo geral, a categoria condições de produção, enfatizando o significado do meme a partir da reflexão do seu espaço-tempo de circulação, endereçamento a seus interlocutores, finalidade.

Na sequência, seguem questões da próxima noção abordada, a do conteúdo temático.

Questões referentes ao conteúdo temático (retomar todos os memes da fase 1)

-Qual a ideia ou a informação que está sendo veiculada por esse meme? Como sabemos disso? -Como essa ideia ou informação está sendo convertida: é engraçado? É irônico? É crítica para quem?

-Quem poderia gostar desse meme? E o que isso nos diz, em relação ao seu conteúdo temático? -Quem não gostaria desse meme? E o que isso nos diz, em relação ao seu conteúdo temático? -Quais são os temas e as posições contempladas por esse meme?

-O que esses temas e posições nos dizem sobre os diferentes grupos sociais que existem em relação ao seu conteúdo temático?

- O que esse meme nos diz sobre o mundo ou sobre uma visão específica de mundo?

As questões produzidas preocupam-se em oportunizar ao aluno-leitor uma leitura que enfatiza aspectos das relações dialógicas do conteúdo temático do meme, como, a questão do humor, por se tratar de uma característica essencial do meme, já que se trata de um aspecto contextualmente situado. Outro aspecto diz respeito ao espaço de afinidade (MACIEL; TAKAKI, 2015) ou de distanciamento que indicam ou a homogeneização ou a heterogeneidade, dependendo dos valores representados pelas comunidades sociais em que o meme está circulando ou sendo replicável. Em outras palavras, reporta-se ao "fato de ser atravessado constitutivamente por outros discursos, por outras vozes que representam diferentes lugares sociais que se estabilizam e se desestabilizam durante o processo de replicação" (SILVA, 2016).

Neste caso específico, o objetivo é que o aluno perceba que o espaço de afinidade dos memes 1, 2 e 3 são espaços para visões homofóbicas e o do meme 4 para posições contra o homofobismo, já que satiriza o fato relacionado a um projeto de lei que tratou da "cura gay". As características desse meme se diferem das características dos outros memes selecionados pela ausência de imagens e por apresentar uma relação dialógica de assimilação contra o discurso homofóbico. 
Após, seguem questões que abordam a estrutura composicional e o estilo.

\section{Questões referentes à estrutura composicional e ao estilo (análise linguística)}

a. Meme 1:

-Explique sua constituição visual: é uma foto? É um vídeo? De quem: pessoa conhecida ou desconhecida? Essa escolha é importante para o significado deste meme? Por quê?

-Em relação ao texto verbal:

- O pronome "sua" faz referência ao quê? O uso desse pronome estabelece um valor semântico de posse? Explique.

-O uso do substantivo "viadagem" neste meme pode ser considerado uma marca de discurso homofófico? Explique.

b. Meme 2:

-Explique sua constituição visual: explique o processo de remixagem de imagem utilizado.

-O texto verbal "amai-vos uns aos outros": por quem ele está sendo dito? Esse dizer representa que tipo de discurso?

-O texto verbal “menos aquele viadinho ali, né?" está sendo dito por quem? Esse dizer representa que tipo de discurso?

-O que se pode concluir sobre a relação entre o texto visual e o verbal neste meme?

c. Meme 3:

- Em relação ao texto verbal: a primeira afirmação "não é fobia" poderia estar no lugar da segunda, sem provocar sentido diferente? Explique.

-Explique a relação entre o texto visual e o verbal neste meme.

d. Meme 4:

- O uso da cor rosa dos corações ao fundo podem ser considerados recursos visuais constitutivos do meme em questão? Justifique.

-O advérbio "agora" expressa um tempo sócio-histórico em relação a um fato ocorrido na época de circulação deste meme: qual é esse "agora"?

-Explique a relação estabelecida pela expressão "são iguais a".

- De acordo com o texto, quais são as duas categorias de gays existentes neste "agora"? A partir desta informação, é válido inferirmos que o autor deste meme é favorável a "cura gay”? Justifique. 
Nas questões em que são mobilizadas as categorias estrutura composicional e estilo a prática de análise linguística é concebida, como já dito anteriormente, na perspectiva procedimental, para dar conta dos aspectos enunciativos envolvidos no funcionamento sóciodiscursivo do gênero meme.

Dessa forma, no caso dos memes selecionados, por se tratar de uma hipermídia de base em foto (ROJO; BARBOSA, 2015), quanto à estrutura composicional, é fundamental a identificação das suas partes constitutivas, ou seja, da sobreposição de material textual escrito na imagem e suas relações dialógicas. Já, quanto ao estilo, observa-se a utilização e os efeitos de sentido do material textual escrito, como, as escolhas lexicais, a ordem das estruturas sintáticas, o arranjo desses recursos linguísticos escolhidos - e da linguagem não-verbal fotograma, desenho e as cores.

A seguir, a atividade de finalização do módulo.

\section{$3^{\text {a }}$ fase: Aulas 4 e 5}

O módulo é encerrado com a solicitação ao aluno para que produza seu próprio meme contra a homofobia. Se possível, esta produção pode ser realizada no laboratório de informática da escola ou com o próprio celular do aluno. Depois da reescrita, se for o caso, os memes circulam na página dos alunos em redes sociais ou em grupos de whatsapp, criando uma manifestação na comunidade escolar.

Esta atividade, embora seja de produção textual, a consideramos também como parte constitutiva da prática de leitura crítica que se deseja construir em sala de aula. É o momento que o aluno é convocado a produzir sua contrapalavra para todos os enunciados lidos e analisados. Instrumentalizado pelos conhecimentos adquiridos por meio das atividades de leitura-analítica, o aluno produz a leitura réplica que se concretiza em uma dada situação de interação verbal. O aluno está situado em um determinado contexto sócio-histórico para interagir socialmente por meio de linguagens próprias de seu tempo.

Portanto, consideramos que as noções bakhtinianas convocadas nesta atividade reportam-se às relações dialógicas estabelecidas em todo seu projeto de dizer, ou, das condições de produção do enunciado. Diferentemente da finalidade dos memes 1, 2, e 3 lidos nas outras aulas, que é a de reproduzir ou representar uma situação de conteúdo homofóbico de forma lúdica com intenção humorística, a produção solicitada ao aluno-leitor tem a finalidade de 
instaurar um questionamento e/ou uma problematização, ao converter em seus memes conteúdos contra a homofobia.

\section{Considerações finais}

As discussões em torno das perspectivas delimitadas neste artigo revelam o quanto é complexo o processo de elaboração didática para a prática de leitura e análise linguística condizente com uma perspectiva dialógica de linguagem. No âmbito escolar, o trabalho com os gêneros discursivos cria a necessidade de se buscar caminhos cada vez mais satisfatórios. Por isso, consideramos que a proposta didática apresentada sinaliza caminhos possíveis a uma orientação metodológica que nos parece coerente com a perspectiva de linguagem assumida.

Podemos constatar que, no geral, as práticas de leitura e de análise linguística foram viabilizadas por meio de uma seleção de textos-enunciados que priorizou a diversidade de gêneros, como, por exemplo, meme, propaganda televisiva/vídeo e comentário. Pontuamos que essa seleção revelou a preocupação em criar condições favoráveis para o aluno se assumir como interlocutor no processo de leitura e análise linguística em sala de aula.

Os questionamentos, as atividades elaboradas convocaram as relações dialógicas das condições de produção dos enunciados, contemplando alguns de seus parâmetros constitutivos, de acordo com a perspectiva bakhtiniana, a saber: papel social do locutor, papel social do interlocutor, finalidade e espaço-tempo de circulação. Da mesma maneira ocorreu em relação às questões referentes ao conteúdo temático, estrutura composicional e estilo. Observamos subjacentes ao movimento pedagógico realizado um modo didático de lidar com o gênero discursivo como objeto de ensino e aprendizagem, na abordagem transdisciplinar do gênero em sala de aula (ROJO, 2008), tratamento que se diferencia, quando tomamos essa noção como objeto privilegiado de ensino. A abordagem transdisciplinar, ao contrário da última, ultrapassa barreiras, transita, refrata valores ideológicos no sentido bakhtiniano. O gênero, tratado como “objeto privilegiado de ensino", tende a ser reduzido ao estudo de mais uma categoria estanque de análise, a um aplicacionismo de regras e formas.

Neste momento de elaboração didática, se ultrapassou o status da hipervalorização da alimentação temática para a prática de leitura. É muito comum, nas aulas de Língua Portuguesa, a crença de que somente solicitar a opinião do aluno sobre o assunto do texto lido pode ser responsável pela compreensão ativa do enunciado primeiro. Os chamados exercícios de interpretação é que garantiriam aos alunos a capacidade de engendrar uma resposta, seja de 
concordância ou discordância. Sem desmerecer esse tipo de exercício, sabemos que há um certo perigo que os rondam. Em situação de ensino-aprendizagem, proporcionar somente momentos interativos de conversa sobre o texto pode levar aluno e professor a um esvaziamento discursivo em relação ao processo de produção de sentidos do enunciado. É como se o texto-enunciado perdesse seu valor no processo.

Daí, a visão fragmentada e descontextualizada sobre a prática de análise linguística. A instauração na práxis do professor de língua materna deste modo descontextualizado de ensino ocorre porque ainda não se internalizou a concepção de que é o intuito discursivo que determina o gênero do discurso, a forma de estruturação do texto, o tom autorizado do discurso, e, portanto, estudar gramática é refletir sobre o uso linguístico, o efetivo exercício da linguagem.

Dessa forma, concluímos que, na aula de leitura e análise linguística, ao se buscar a compreensão do funcionamento sócio-discursivo dos memes, ao se observar suas relações dialógicas com o enunciado já-dito e com o pré-figurado, e as marcas linguístico-enunciativas que arregimentaram tais relações, o professor instrumentaliza o aluno para desenvolver posturas críticas diante do texto-enunciado por meio da reflexão do uso da língua.

\section{Referências}

ACOSTA-PEREIRA, R.; RODRIGUES, R. H. Gêneros como articuladores do ensino e da aprendizagem das práticas de linguagem. In: SILVA, W. R.; LIMA, P. da S.; MOREIRA, T. M. (Orgs.). Gêneros na prática pedagógica: diálogos entre escolas e universidades. Campinas, SP: Pontes Editores, 2016, p. 25-48.

BAKHTIN, M. M. Estética da criação verbal. 4. ed. São Paulo: Martins Fontes, 2003.

. O discurso no romance. In: Questões de literatura e de estética (A teoria do romance). 4. ed. São Paulo: Hucitec, 1998. p. 71-164.

BAKHTIN, M. M; VOLOCHINOV, V. N. Marxismo e filosofia da linguagem. 4. ed. São Paulo: Hucitec, 1988.

BRAGA, B. E. Um protótipo didático para o multiletramento com o gênero meme para um nono ano. 2018. 107 f. Dissertação (Mestrado) - Mestrado Profissional em LetrasPROFLETRAS, Universidade Estadual de Maringá, Maringá, 2018.

BRASIL. Ministério da Educação. Base Nacional Comum Curricular. Língua Portuguesa: competências específicas para o ensino fundamental. Brasília, DF: MEC/SEF, 2017, p.65-190.

BRASIL. Ministério da Educação. Parâmetros Curriculares Nacionais: Língua Portuguesa: terceiro e quarto ciclos. Brasília, DF: MEC/SEF, 1998. 
DI FANTI, M. G. C. A linguagem em Bakhtin: pontos e pespontos. Veredas: Rev. Est. Ling. Juiz de Fora, v. 7, n. 1, p. 95-111, jan./dez. 2003.

GARCIA, C.B; SILVA, F.D.S.; FELÍCIO,R.P. Projet(o)arte: uma proposta didática. In: ROJO, R; MOURA, E. (Orgs.) Multiletramentos na escola. São Paulo: Parábola Editorial, 2012, p.123146.

GERALDI, J. W. Portos de passagem. São Paulo: Martins Fontes, 1991.

HALTÉ, J. F. O espaço didático e a transposição. Fórum Linguístico, Florianópolis, p. 117139, jul./dez. 2008.

HILA, C. V. D. Ressignificando a aula de leitura a partir dos gêneros textuais. In: NASCIMENTO, E. L. (Org.). Gêneros textuais: da didática das línguas aos objetos de ensino. $1^{a}$ ed. São Carlos: Editora Claraluz, 2009, p. 151-194.

MACIEL; R.F.; TAKAKI, N.H. Novos letramentos pelos memes: muito além do ensino de línguas. In: JESUS, D. M de; MACIEL, R. F. (Orgs). Olhares sobre tecnologias digitais: linguagens, ensino, formação e prática docente. Campinas: Pontes Editores, 2015, p.53-82.

PARANÁ. Secretaria de Estado da Educação. Diretrizes Curriculares da Educação Básica: Língua Portuguesa. Curitiba: SEED, 2008.

PETITJEAN, A. Importância e limites da noção de transposição didática para o ensino do francês. Fórum Linguístico, Florianópolis, p. 83-116, jul./dez. 2008.

RITTER, L. C. B. Práticas de leitura/análise linguística com crônicas no Ensino Médio: proposta de elaboração didática. 2012. 242 f. (Tese) -Doutorado em Estudos da Linguagem, Universidade Estadual de Londrina, Londrina, 2012.

RODRIGUES, R. H. Pesquisa com os gêneros do discurso na sala de aula: resultados iniciais. In: Revista Acta Scientarium - Language and Culture, Maringá, v. 30, n. 2, p. 169-175, 2008.

. A constituição e o funcionamento do gênero jornalístico: cronotopo e dialogismo. 2001. 347. Tese (Doutorado em Linguística Aplicada e Estudos da Linguagem) - Pontifícia Universidade Católica de São Paulo, São Paulo.

ROJO, R. Gêneros de discurso/texto como objeto de ensino de línguas: um retorno ao trivium? In: SIGNORINI, I. (Org.). (Re)discutir texto, gênero e discurso. São Paulo: Parábola Editorial, 2008. p. 73-108.

. Gêneros do discurso e gêneros textuais: questões teóricas e aplicadas. In: MEURER, J. L.; BONINI, A.; MOTTA-ROTH, D. (Org.). Gêneros: teorias, métodos, debates. São Paulo: Parábola, 2005. p. 184-293.

ROJO, R.; BARBOSA, J. P. Hipermodernidade, multiletramentos e gêneros discursivos. São Paulo: Parábola, 2015.

SILVA, A. A. da. Memes virtuais: gêneros do discurso, dialogismo, polifonia e heterogeneidade enunciativa. In: Revista Travessias, v. 10, n. 3, p. 341-361, 2016.

SOBRAL, A. Do dialogismo ao gênero: as bases do pensamento do Círculo de Bakhtin. Campinas: Mercado de Letras, 2009. 
VIANA, M. R. A elaboração didática nos documentos oficiais de ensino e na sala de aula de uma rede municipal do Estado de Santa Catarina. Disponível em: <http://www. filologia.org.br/ixcnlf/9/62.htm> Acesso em: 17 maio 2010.

Recebido em 30 de maio de 2018. Aceito em 17 de setembro de 2018. 